УДК 378.147.091.33-027.22:577.1:616-08-039.76

DOI https://doi.org/10.26661/2522-4360-2021-2-16

\title{
РОЛЬ І МІСЦЕ БІОЛОГІЧНОЇ ХІМІЇ У СИСТЕМІ ПІДГОТОВКИ ФАХІВЦІВ 3 МЕДИЧНОЇ РЕАБІЛІТАЦІї
}

\author{
Білик Л. В. \\ кандидатка педагогічних наук, \\ проректорка з науково-педагогічної роботи та післядипломної освіти \\ Черкаська медична академія \\ вул. Хрещзатик, 215, Черкаси, Украӥна \\ orcid.org/0000-0002-0054-4628 \\ medacademy@ukr.net \\ Chicap O. A. \\ кандидатка педагогічних наук, \\ завідувачка кафедри природничих дисииплін \\ Черкаська медична академія \\ вул. Хрещзатик, 215, Черкаси, Украӥна \\ orcid.org/0000-0002-4624-2959 \\ snisar.elena20@ukr.net \\ Ліфер К. О. \\ викладачка кафедри природничих дисциплін \\ Черкаська медична академія \\ вул. Хрещатик, 215, Черкаси, Україна \\ orcid.org/0000-0001-6052-4082 \\ karina.lifer@gmail.com
}

Ключові слова: медична освіта, компетентності, медична реабілітація, біохімічні прочеси в організмі людини, біохімічні дослідження.
У статті проаналізовано роль і місце біологічної хімії як дисципліни медикобіологічного циклу в процесі підготовки фахівців з медичної реабілітації. Оскільки в Україні є багато людей, які перенесли захворювання, після яких необхідна тривала реабілітація (Covid-19, захворювання серцево-судинної та нервової систем, опорно-рухового апарату, поранення під час бойових дій на Сході України), питання розбудови та реформування системи реабілітації у сфері охорони здоров'я є надзвичайно актуальним. Вивчено сучасне законодавство України про реабілітацію у сфері охорони здоров'я. Охарактеризовано систему підготовки фахівців 3 реабілітації та визначено основні завдання біологічної хімії для формування спеціаліста 3 глибоким розумінням біохімічних процесів людського організму при різних формах патології, готового використовувати результати біохімічних досліджень для контролю стану пацієнта, реакцій його організму на проведені реабілітаційні заходи. Наведено основні компетентності майбутніх фахівців з медичної реабілітації, формування яких забезпечує вивчення біологічної хімії. До таких компетентностей належить здатність аналізувати результати біохімічних досліджень, які застосовуються для діагностики найбільш розповсюджених захворювань людини, розуміння діагностичних можливостей сучасних лабораторій, уміння використовувати біохімічні методики для контролю ефективності заходів 3 медичної реабілітації. Акцентовано увагу на основних біохімічних маркерах найбільш поширених захворювань, які потребують 
реабілітації. Оскільки кінезіотерапія займає важливе місце у реабілітаційних планах, особливу увагу приділено питанням біохімії м'язів, м’язового скорочення, відновлення м'язової діяльності.

Зроблено висновок про те, що біологічна хімія $є$ однією $з$ фундаментальних дисциплін у підготовці майбутніх фахівців з медичної реабілітації та забезпечує грунтовне розуміння процесів в організмі при різних формах патології. Це важливо для розробки плану реабілітації та контролю ефективності заходів під час усіх реабілітаційних періодів.

\title{
THE ROLE AND PLACE OF BIOLOGICAL CHEMISTRY IN THE SYSTEM OF TRAINING OF MEDICAL REHABILITATION SPECIALISTS
}

\author{
Bilyk L. V. \\ Ph.D. in Pedagogy, \\ Vice-Rector for Scientific-Pedagogical Work and Postgraduate Education \\ Cherkasy Medical Academy \\ Khreschatyk str., 215, Cherkasy, Ukraine \\ orcid.org/0000-0002-0054-4628 \\ medacademy@ukr.net \\ Snisar O. A. \\ Ph.D. in Pedagogy, \\ Head of the Department of Natural Sciences \\ Cherkasy Medical Academy \\ Khreschatyk str., 215, Cherkasy, Ukraine \\ orcid.org/0000-0002-4624-2959 \\ snisar.elena20@ukr.net \\ Lifer K. $\mathbf{O}$. \\ Lecturer at the Department of Natural Sciences \\ Cherkasy Medical Academy \\ Khreschatyk str., 215, Cherkasy, Ukraine \\ orcid.org/0000-0001-6052-4082 \\ karina.lifer@gmail.com
}

Key words: medical education, competencies, medical rehabilitation, biochemical processes in the human body, biochemical research.
The article analyses the role and place of biological chemistry as a discipline of the medical-biological cycle in the process of training of medical rehabilitation specialists. Given that many people in Ukraine have suffered diseases that require long-term rehabilitation: Covid-19, cardiovascular diseases, neurological disorders, musculoskeletal disorders, injuries during the military operations in Eastern Ukraine, the development and reformation of the system of rehabilitation in the field of healthcare is extremely topical. The current legislation of Ukraine on rehabilitation in the field of healthcare was studied. The system of training of rehabilitation specialists was characterized and the main tasks of biological chemistry were determined for the formation of a specialist with a deep understanding of biochemical processes of the human body in various forms of pathology, ready to use the results of biochemical studies to monitor the patient's condition, his/her body's reactions to rehabilitation. The main competencies of future medical rehabilitation specialists were listed, the formation of which provides the study of biological chemistry. Such competencies include the ability to analyse the results of biochemical research used to diagnose the most common human diseases, the understanding of the diagnostic capabilities of modern laboratories, the 
ability to use biochemical techniques to monitor the effectiveness of medical rehabilitation during all rehabilitation periods. The main biochemical markers in the most common diseases that require rehabilitation were highlighted. As kinesiotherapy takes an important place in rehabilitation plans, a special attention was paid to the issues of biochemistry of muscles and muscle contraction, recovery from muscle activity.

It was concluded that biological chemistry is one of the basic fundamental disciplines in the training of future medical rehabilitation specialists and it provides a thorough understanding of the processes in the body in various forms of athology, which is important for developing a rehabilitation plan and monitoring the effectiveness of measures during all rehabilitation periods.

Постановка проблеми. Питання реабілітації пацієнтів після важких захворювань або травм є настільки актуальним для сучасної України, що у грудні 2020 року Верховна Рада ухвалила Закон «Про реабілітацію у сфері охорони здоров'я» [6]. Цей Закон має створити в Україні умови для формування сучасної системи реабілітації у сфері охорони здоров'я, яка функціонуватиме за стандартами Свросоюзу [7]. У контексті реформування системи реабілітації пацієнтів постає питання підготовки кадрів до впровадження положень Закону. До фахівців 3 медичної реабілітації належать лікарі фізичної та реабілітаційної медицини, фізичні терапевти, ерготерапевти, сестри медичні з реабілітації [6]. Підходи до викладання дисциплін не тільки професійної підготовки, а i психолого-педагогічних та медико-біологічних як за змістовим компонентом, так і за методичними засадами мають відповідати сучасним вимогам та забезпечувати програмні результати навчання майбутніх фахівців з медичної реабілітації.

Роботи Ю. Долинного, В. Зюзіна, Т. Зінченко, Ю. Лянного присвячені проблемам підготовки фахівців 3 фізичної реабілітації на базі факультетів фізичного виховання і спорту. Проте такий підхід характеризується акцентом на фізичних засобах реабілітації, таких як лікувальна фізкультура, оздоровчий біг, або взагалі значна увага приділяється реабілітації спортсменів після травм чи великих фізичних навантажень.

Підготовка фахівців 3 медичної реабілітації на базі закладів медичної освіти дає можливість змінити ситуацію, застосувати мультидисциплінарний підхід, адже важливе значення має система оцінки життєдіяльності та здоров'я пацієнта на всіх рівнях надання медичної допомоги. У процесі роботи мультидисциплінарної реабілітаційної команди $з$ пацієнтом мають формуватися реабілітаційні цілі та індивідуальний реабілітаційний план [5].

Питання впровадження сучасних підходів та реформування в Україні такої галузі, як реабілітаційна медицина, грунтовно вивчали Т. Бакалюк, А. Голяченко, В. Малахов, І. Мисула, Г. Кошелєва, В. Родін, Н. Сидлярук, І. Сисоєнко, О. Яремчук. Зарубіжний досвід у сфері медичної реабілітації та перспективи його використання в Україні були проаналізовані I. Берлінець. Дослідниця наголошує на особливій актуальності зазначеного питання в період військового конфлікту та пропонує пріоритетні завдання розбудови проєвропейської системи реабілітації в Україні [1]. Попри свою актуальність, проблема удосконалення системи підготовки фахівців з медичної реабілітації висвітлена в роботах вітчизняних науковців недостатньо.

Мета статті - проаналізувати роль і місце біологічної хімії як дисципліни медико-біологічного циклу в процесі підготовки фахівців 3 медичної реабілітації.

Виклад основного матеріалу дослідження. В Україні сьогодні склалась така ситуація, що пацієнти після проходження лікування потребують тривалої реабілітації. Основні групи таких пацієнтів - це люди, які перенесли Covid-19, учасники бойових дій на Сході України після поранень, а також пацієнти після інсультів, інфарктів, оперативних втручань, пацієнти із захворюваннями опорно-рухового апарату. Це вимагає розбудови та реформування системи реабілітації у сфері охорони здоров'я та підготовки фахівців, що можуть адаптувати свою практичну діяльність до змінних умов.

Система підготовки фахівців з реабілітації включає не лише дисципліни циклу спеціальної фахової підготовки, які безпосередньо формують здатність ефективно реалізовувати програму фізичної терапії та ерготерапії, а і фундаментальні дисципліни, однією з яких є біологічна хімія. Майбутні фахівці 3 медичної реабілітації повинні мати глибоке розуміння біохімічних процесів у людському організмі як у нормі, так і за різних форм патології, адже результати біохімічних досліджень за наявності певних захворювань мають важливе діагностичне значення, можуть використовуватися для контролю стану пацієнта, реакції його організму на проведені реабілітаційні заходи.

Біологічна хімія у системі підготовки фахівців 3 медичної реабілітації повинна забезпечувати як компетентності, які необхідні для медичних спеціалістів різних профілів, так і спеціальні фахові компетентності. Саме компетентнісний підхід є одним 3 найголовніших методологічних підходів у медичній освіті, оскільки він забезпечує єдність освіти, наукових досліджень і клінічної практики та орієнтований на підготовку студентів, готових до розв'язання професійних проблем у майбутньому [2, с. 75]. 
До компетентностей, які формує біологічна хімія і які необхідні для медичних спеціалістів усіх профілів, можна віднести такі:

- володіння знаннями про біохімію метаболічних процесів у людському організмі, основи адаптації, біохімічні аспекти харчування;

- проведення біохімічної оцінки порушень білкового, вуглеводного, ліпідного, гормонального обмінів, а також недостатності вітамінів, макро- та мікроелементів;

- розуміння діагностичних можливостей сучасних лабораторних досліджень, основ функціональної та клініко-лабораторної діагностики;

- знання особливостей преаналітичного етапу лабораторних досліджень, правил підготовки пацієнтів до лабораторного обстеження;

- вміння аналізувати результати біохімічних досліджень та зміни біохімічних і ферментативних показників, які застосовуються для діагностики найбільш розповсюджених захворювань людини.

До спеціальних фахових компетентностей, які важливі для фахівців 3 медичної реабілітації та формуються у курсі біологічної хімії, належать такі:

- розуміння біохімічних процесів, що супроводжують патологічні стани, які піддаються корекції заходами реабілітації;

- використання біохімічних методик під час проведення реабілітаційного обстеження та під час усіх реабілітаційних періодів;

- контроль за допомогою біохімічних досліджень ефективності заходів 3 медичної реабілітації у травматології, ортопедії, неврології, нейрохірургії, кардіології, пульмонології тощо;

- використання біохімічних методик для контролю за процесами відновлення після фізичних вправ під час проведення реабілітаційних заходів.

Оскільки кінезіотерапія займає важливе місце у реабілітаційних планах під час лікування захворювань внутрішніх органів та порушень опорно-рухового апарату, під час викладання біологічної хімії майбутнім фахівцям 3 реабілітації необхідно акцентувати увагу на біохімії м'язів і м'язового скорочення, біохімічних маркерах для оцінювання стану м'язів, а також на біохімічних факторах втоми, процесах відновлення під час м'язової діяльності в нормі та при патології, впливі гормонів на опорно-рухову систему.

Малорухливий спосіб життя і сидяча робота, пов'язана 3 комп'ютером, призводять до того, що $80 \%$ населення страждає на захворювання опорно-рухового апарату. Серед найбільш поширених - дегенеративно-дистрофічні захворювання хребта, викривлення хребта, ураження міжхребцевих дисків, остеохондроз [9]. 3 огляду на це особлива увага має приділятися вивченню лабораторних методів діагностики захворювань кісткової та сполучної тканин, зокрема артриту, артрозу, подагри, ревматизму, остеохондрозу.

Iз захворюваннями хребта тісно пов'язані вертеброгенні ураження периферичної нервової системи, які істотно погіршують якість життя, призводять до інвалідизації. Вертеброгенні неврологічні ураження супроводжуються болем, парестезією кінцівок, обмеженням рухів у відповідному відділі хребта, головним болем, запамороченням [3]. Значно частіше у медичній практиці почали траплятися тунельні синдроми - неврологічні захворювання, пов'язані 3 тривалим користуванням комп'ютерною мишкою. Саме тому у програмі біологічної хімії для майбутніх реабілітологів окремим блоком мають плануватися заняття із застосування біохімічних методів при захворюваннях периферичної нервової системи. Не варто забувати про питання біохімічних змін ліквору, що супроводжують такі захворювання нервової системи, як менінгіт, внутрішньомозкові крововиливи, пухлини.

Серцево-судинні захворювання протягом багатьох років залишаються основною причиною передчасної смерті та інвалідизації населення, призводять до зростання витрат на охорону здоров’я. 31990 до 2019 року кількість випадків серцево-судинних захворювань зросла майже вдвічі (з 271 мільйона до 523 мільйонів) [8]. Майбутні фахівці достатньо часто у своїй практичній діяльності будуть забезпечувати реабілітацію пацієнтів після перенесених інсультів та інфарктів. Для глибокого розуміння процесів, що проходять в організмі хворого, важливим $є$ знання біохімічних показників організму людини при серцево-судинних захворюваннях, розуміння сучасних біохімічних маркерів серцево-судинних захворювань.

Наприкінці 2019 року світ зустрівся 3 новим і надзвичайно небезпечним захворюванням - COVID-19. Після перенесеного захворювання спостерігаються тяжкі наслідки: у пацієнтів на 20-30\% знижується функція легень, у 12\% осіб розвивається серцева недостатність, порушуються функції печінки та нирок, розвиваються неврологічні симптоми, зокрема знижуються когнітивні функції, спостерігаються синдроми хронічної втоми та Гійєна-Барре. Останній за тяжкого перебігу може призвести до паралічу $[4$, с. 76$]$. Протягом останнього року з'явилися та стали широковживаними такі терміни: «постковідний синдром», «довготривалий COVID». Проведення якісної медичної реабілітації пацієнтів, що перенесли COVID-19 та мають постковідний синдром, $є$ важливим у їх остаточному одужанні та поверненні до нормального життя. Як і про саме захворювання, так і про заходи медичної реабілітації після COVID-19 медичні фахівці ще багато не знають, але у них вже $\epsilon$ 
достатній досвід успішного застосування певних планів реабілітації. У тематичні плани дисциплін, що викладаються під час підготовки реабілітологів, мають бути включені питання, що стосуються реабілітації пацієнтів, які перенесли COVID-19. У курсі біологічної хімії під час ознайомлення 3 клініко-біохімічними характеристиками захворювань основних систем органів необхідно включити питання впливу на них COVID-19. Особлива увага має приділятися клініко-біохімічній характеристиці патологічних процесів у легенях та серцево-судинній системі, які найчастіше вражає коронавірусна інфекція.
Реабілітація хворих після COVID-19 може тривати декілька місяців і вимагає нових підходів.

Висновки. Реформування системи реабілітаційної медицини має на меті запровадження мультидисциплінарного підходу для забезпечення максимально можливого рівня відновлення функціонування організму пацієнта. Біологічна хімія $\epsilon$ однією з тих базових дисциплін у підготовці майбутніх фахівців з медичної реабілітації, яка забезпечує грунтовне розуміння процесів в організмі за різних форм патології, що є важливим для розробки плану реабілітації та контролю ефективності заходів під час усіх реабілітаційних періодів.

\section{ЛIТЕРАТУРА}

1. Берлінець І.А. Зарубіжний досвід у сфері медичної реабілітації: перспективи використання в Україні. Державне управління: удосконалення та розвиток. 2019. № 4. URL: http://www.dy.nayka.com.ua/ ?op $=1 \& \mathrm{z}=1416$. (дата звернення: 03.08.2021).

2. Білик Л.В., Шевченко О.Т. Методологічні та психологічні підходи професійної підготовки студентів спеціальності «Медсестринство» до медичної реабілітації. Theoretical and empirical scientific

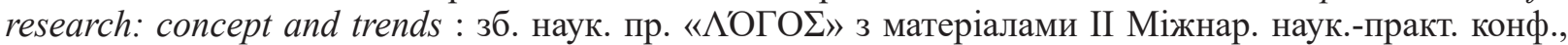
м. Оксфорд, 28 травня 2021 р. Вінниця-Оксфорд : Свропейська наукова платформа, P.C. Publishing House, 2021. T. 2. C. 74-78.

3. Коваленко О.С. Захворювання периферичної нервової системи: оптимізація лікування. URL: https://neuronews.com.ua/ua/archive/2012/2\%2837\%29/article-596/zahvoryuvannya-periferichnoyinervovoyi-sistemi-optimizaciya-likuvannya\#gsc.tab=0 (дата звернення: 02.08.2021).

4. Малий В.П., Андрусович I.В. Клініка та ускладнення коронавірусної хвороби COVID-19 з елементами патогенезу. Міжнародний медичний журнал. 2020. Т. 26, № 3. С. 72-78.

5. Офіційний сайт Міністерства охорони здоров'я України. URL:https://moz.gov.ua/article/news/moz-ukrainirozrobljae-kompleksnij-pidhid-do-nadannja-poslug-z-medichnoi-reabilitacii (дата звернення: 3.07.2021).

6. Про реабілітацію у сфері охорони здоров’я : Закон України від 03.12.2020 p. № 1053-IX. URL: https://zakon.rada.gov.ua/laws/show/1053-20\#Техt (дата звернення: 31.07.2021).

7. Сайт Офіційного інтернет-представництва Президента України. URL: https://www.president.gov.ua/ news/glava-derzhavi-pidpisav-zakon-pro-reabilitaciyu-u-sferi-ohor-65833 (дата звернення: 31.07.2021).

8. Серцево-судинні захворювання - головна причина смерті українців. Висновки 3 дослідження глобального тягаря хвороб у 2019 році. Центр громадського здоров'я Міністерства охорони здоров'я України : вебсайт. URL: https://phc.org.ua/news/sercevo-sudinni-zakhvoryuvannya-golovna-prichinasmerti-ukrainciv-visnovki-z-doslidzhennya (дата звернення: 02.08.2021).

9. Чорний К., Худецький І., Антонова-Рафі Ю. Роботизований програмно-апаратний комплекс для діагностики та лікування захворювань хребта за допомогою тракційної терапії. URL: https://ela.kpi.ua/ bitstream/123456789/33736/1/BmET-2018-1_p92-98.pdf (дата звернення: 03.08.2021).

\section{REFERENCES}

1. Berlinets I.A. (2019) Zarubizhnyi dosvid u sferi medychnoi reabilitatsii: perspektyvy vykorystannia v Ukraini. [Foreign experience in the field of medical rehabilitation: prospects for use in Ukraine]. Derzhavne upravlinnia: udoskonalennia ta rozvytok. Vol. 4. URL: http://www.dy.nayka.com.ua/?op=1\&z=1416 (access date: 03.08.2021).

2. Bilyk L.V., Shevchenko O.T. (2021) Metodolohichni ta psykholohichni pidkhody profesiinoi pidhotovky studentiv spetsialnosti Medsestrynstvo do medychnoi reabilitatsii [Methodological and psychological approaches to professional training of students majoring in Nursing for medical rehabilitation]. Theoretical and empirical scientific research: concept and trends: zb. nauk. pr. " $\Lambda \mathrm{OHO} \Sigma$ " z materialamy II Mizhnar. nauk.-prakt. konf., m. Oksford, 28 travnia 2021 r. Vinnytsia-Oksford: Yevropeiska naukova platforma, P.C. Publishing House. Vol. 2. P. 74-78.

3. Kovalenko O.Ye. (2012) Zakhvoriuvannia peryferychnoi nervovoi systemy: optymizatsiia likuvannia. [Diseases of the peripheral nervous system: treatment optimization]. URL: https://neuronews.com.ua/ua/ archive/2012/2\%2837\%29/article-596/zahvoryuvannya-periferichnoyi-nervovoyi-sistemi-optimizaciyalikuvannya\#gsc.tab=0 (access date: 02.08.2021). 
4. Malyi V.P., Andrusovych I.V. (2020) Klinika ta uskladnennia koronavirusnoi khvoroby COVID-19 z elementamy patohenezu. [Clinic and complications of COVID-19 coronavirus disease with pathogenesis elements]. Mizhnarodnyi medychnyi zhurnal. Vol. 26, № 3. P. 72-78.

5. Ofitsiinyi sait Ministerstva okhorony zdorovia Ukrainy. URL: https://moz.gov.ua/article/news/moz-ukrainirozrobljae-kompleksnij-pidhid-do-nadannja-poslug-z-medichnoi-reabilitacii (access date: 03.08.2021).

6. Pro reabilitatsiiu u sferi okhorony zdorovia : Zakon Ukrainy vid 03.12.2020 r. № 1053-IX. [On rehabilitation in healthcare field: Law of Ukraine from December 3, 2020 No. 1053-IX]. URL: https://zakon.rada.gov. ua/laws/show/1053-20\#Text (access date: 31.07 .2021 ).

7. Sait Ofitsiinoho internet-predstavnytstva Prezydenta Ukrainy. URL: https://www.president.gov.ua/news/ glava-derzhavi-pidpisav-zakon-pro-reabilitaciyu-u-sferi-ohor-65833 (access date: 31.07.2021).

8. Sertsevo-sudynni zakhvoriuvannia - holovna prychyna smerti ukraintsiv. Vysnovky z doslidzhennia hlobalnoho tiaharia khvorob u 2019 rotsi. [Cardiovascular diseases are the main cause of death of Ukrainians. Conclusions from the study of the global burden of diseases in 2019]. Veb-sait Derzhavnoi ustanovy 'Tsentr hromadskoho zdorovia Ministerstva okhorony zdorovia Ukrainy”. URL: https://phc.org. ua/news/sercevo-sudinni-zakhvoryuvannya-golovna-prichina-smerti-ukrainciv-visnovki-z-doslidzhennya (access date: 02.08.2021).

9. Chornyi K., Khudetskyi I., Antonova-Rafi Yu. (2018) Robotyzovanyi prohramno-aparatnyi kompleks dlia diahnostyky ta likuvannia zakhvoriuvan khrebta za dopomohoiu traktsiinoi terapii. [Robotic software and hardware complex for diagnosis and treatment of spinal diseases with the help of traction therapy]. URL: https://ela.kpi.ua/bitstream/123456789/33736/1/BmET-2018-1_p92-98.pdf (access date: 03.08.2021). 